\title{
Potensi Antibakteri dari Ekstrak Etanol Spons Agelas cavernosa
}

Andhika Dwi Aristyawan, Noor Erma Sugijanto, Suciati*

Fakultas Farmasi, Universitas Airlangga, Surabaya

*Corresponding author: suciati@ff.unair.ac.id

\begin{abstract}
Background: Sponges from the genus Agelas have been reported to have antimicrobial activity, however there is no report on the antimicrobial activity of Agelas cavernosa. Objective: The aim of the current study is to investigate the antibacterial activity of the ethanolic extract of marine sponge A. cavernosa. Methods: The antibacterial activity of the extract was determined by using microdilution method against Escherichia coli ATCC 25922, Staphylococcus aureus ATCC 6538, Pseudomonas aeruginosa ATCC 27853. Piodonitrotetrazolium chloride reagent was added to visualize the presence of living organism. Results: The ethanolic extract of sponge A. cavernosa inhibited the growth of all bacteria tested, with the highest inhibition against Pseudomonas aeruginosa at MIC 150 ppm. Conclusion: The ethanolic extract of A. cavernosa showed moderate antibacterial activity.
\end{abstract}

Keywords: antibacterial agent, microdilution, sponge, Agelas cavernosa

\begin{abstract}
Abstrak
Pendahuluan: Beberapa spons dari genus Agelas telah dilaporkan memiliki aktivitas antimikroba, namun belum ada laporan tentang aktivitas antimikroba dari Agelas cavernosa. Tujuan: Penelitian ini bertujuan untuk mengetahui aktivitas antibakteri ekstrak etanol dari spons Agelas cavernosa. Metode: Aktivitas antibakteri pada ekstrak ditentukan dengan menggunakan metode mikrodilusi terhadap Escherichia coli ATCC 25922, Staphylococcus aureus ATCC 6538 dan Pseudomonas aeruginosa ATCC 27853. Pereaksi warna $p$ iodonitrotetrazolium chloride ditambahkan dalam sumuran untuk memvisualisasikan adanya bakteri hidup. Hasil: ekstrak etanol dari spons A. cavernosa menghambat pertumbuhan ketiga bakteri uji dengan aktivitas antibakteri tertinggi pada Pseudomonas aeruginosa ATCC 27853 dengan MIC 150 ppm. Kesimpulan: Ekstrak ethanol A. cavernosa menunjukkan aktivitas antibakteri.
\end{abstract}

Kata kunci: antibakteri, mikrodilusi, spons, Agelas cavernosa

\section{PENDAHULUAN}

Di Indonesia penyakit infeksi merupakan salah satu masalah kesehatan yang penting (Kemenkes RI, 2011). Setiap tahunnya dilaporkan sembilan juta orang meninggal karena penyakit infeksi, banyak diantaranya anak-anak berusia di bawah lima tahun mengalami infeksi hingga menyebabkan cacat seumur hidup (WHO, 2018). Adanya bakteri yang resisten terhadap beberapa jenis antibiotika yang dikenal dengan istilah superbugs semakin memperparah kasus infeksi, misalnya pada Eschericia coli, Klebsiella pneumoniae dan Staphyloccus aureus (NIH, 2014). Oleh karena itu diperlukan adanya penemuan antibiotika baru yang diharapkan dapat mengatasi permasalahan ini. Salah satu sumber alternatif dalam penemuan antibiotika adalah bahan alam baik dari tanaman maupun biota laut.
Indonesia memiliki sumber daya alam bahari yang besar. Terdapat beraneka ragam sumberdaya alam hayati laut yang meliputi 300 jenis karang, lebih dari 200 jenis ikan serta beberapa jenis spons (Mokodompit dkk., 2015). Senyawa denan berbagai bioaktivitas, anatara lain: antivirus, antibakteri, antikanker, antileukimia, antiinflamasi, insektisida, dan antihelmintik telah ditemukan dari spons (Kim,2012). Hal ini membuat spons menjadi salah satu hewan laut yang menarik untuk diteliti karena berpotensi besar untuk dikembangkan dalam bidang pengobatan salah satunya sebagai antibakteri (Abubakar dkk.,2011).

Beberapa spons dari genus Agelas telah dilaporkan memiliki aktivitas antibakteri. Ekstrak etanol spons Agelas nakamurai menunjukkan aktivitas antibakteri terhadap Mycobacterium smegmatis dengan zona hambat $22 \mathrm{~mm}(50 \mathrm{mg} / \mathrm{disc})$. Diketahui metabolit 
sekunder yang ikut berperan terhadap aktivitas antibakteri tersebut yaitu Agelasine A-F dan alkaloid bromopirol (Yamazaki dkk., 2015). Ekstrak metanol dari spons Agelas clathrodes dlaporkan memiliki aktivitas antibakteri yang bersifat bakterisida terhadap Escherichia coli, Mycobacterium smegmatis dan bersifat bakteriostatik terhadap Staphylococcus aureus dengan menggunakan metode dilusi. Senyawa yang bertanggung jawab sebagai antibakteri pada $A$. clathrodes adalah Agelasidine (Medeiros dkk., 2006). Spons Agelas cornifera juga dilaporkan memiliki aktivitas antibakteri terhadap beberapa bakteri pathogen antara lain Pseudomonas aeruginosa, Salmonella thypi, Aeromonas hydrophila, dan Vibrio harveyi (Haris dkk., 2013).

Berdasarkan kajian aktivitas antibakteri dari spons genus Agelas, belum ditemukan adanya laporan aktivitas antibakteri dari spons Agelas cavernosa. Oleh karena itu penulis tertarik untuk meneliti aktivitas antibakteri dari spons Agelas cavernosa yang diambil dari sekitar pulau Barrang Lompo, Makassar, Sulawesi Selatan.

\section{BAHAN DAN METODE}

\section{Bahan}

Sampel berupa spons diambil dari perairan di sekitar pulau Barrang Lompo, Makassar, Sulawesi Selatan pada tanggal 17 Mei 2014. Pengambilan sampel ini dilakukan dengan cara scuba diving pada kedalaman $10-12 \mathrm{~m}$ di bawah permukaan air laut. Sampel kemudian dibekukan pada suhu $-20^{\circ} \mathrm{C}$ hingga dilakukan analisa. Identifikasi sampel dilakukan di Laboratorium Ekologi Institut Teknologi Surabaya secara mikroskopis. Sampel spons diidentifikasi sebagai Agelas cavernosa.

Bahan kimia yang digunakan dalam penelitian ini adalah etanol (Merck, p.a), asam sulfat (Merck), barium klorida, dimetilsulfoxid (DMSO), larutan kristal violet, larutan lugol, larutan safranin, pereaksi warna INT $p$ - iodonitrotetrazolium chloride, siprofloksasin pharmaceutical grade (kontrol positif untuk bakteri), nutrient broth, dan larutan normal salin $(0,9 \% \mathrm{NaCl})$.

Bakteri yang digunakan pada penelitian ini adalah Escherichia coli ATCC 25922, Staphylococcus aureus ATCC 6538 dan Pseudomonas aeruginosa ATCC 27853 yang diperoleh dari Unit Layanan Pengujian, Fakultas Farmasi, Universitas Airlangga.

Alat

Alat yang digunakan dalam penelitian ini adalah ultrasonik, rotary evaporator, Laminary Air Flow
Cabinet (LAF), inkubator, freeze dryer, autoklaf, 96well microplate, mikroskop, dan spektrofotometer.

\section{Ekstraksi}

Spons beku dikeluarkan dari freezer dan diletakkan pada suhu ruangan hingga es mencair, lalu spons basah ditimbang (709 g). Permukaan spons dibersihkan dengan cara dibilas menggunakan aquades untuk menghilangkan pengotor mekanis, seperti bintang laut, batu karang kecil, dan kerang. Ukuran spons diperkecil dengan cara dipotong-potong (ukuran sekitar $1 \mathrm{~cm}$ ). Spons selanjutnya dikeringkan dengan freeze dryer. Spons kering selanjutnya dihaluskan dengan blender dan diperoleh serbuk kering spons sebanyak 99,5 g.

Serbuk spons kering diekstraksi dengan menggunakan etanol $96 \%$ dengan bantuan ultrasonik selama 3 x 10 menit tiap ekstraksi. Filtrat dipisahkan dari residu dengan cara disaring. Residu diekstraksi kembali sebanyak 3 kali dengan metode yang sama. Total volume etanol yang digunakan untuk ekstraksi adalah 2 L. Semua filtrat dikumpulkan dan diuapkan dengan rotary evaporator pada suhu $40^{\circ} \mathrm{C}$ sehingga diperoleh ekstrak kental sebanyak 7,5 g.

\section{Uji antibakteri}

Uji aktivitas antibakteri dilakukan secara in vitro dengan metode mikrodilusi menggunakan 3 macam bakteri yaitu: adalah Escherichia coli ATCC 25922, Staphylococcus aureus ATCC 6538 dan Pseudomonas aeruginosa ATCC 27853. Adapun pelaksanaan uji antibakteri ini dibagi dalam 3 tahap.

\section{Penyiapan bakteri uji}

Bakteri dibiakkan pada media nutrient agar (NA) pada suhu $37^{\circ} \mathrm{C}$ selama 24 jam. Kemudian dilakukan pembuatan suspensi bakteri uji dengan cara mengambil biakan bakteri dan dilarutkan dalam larutan salin $(0,9 \%$ $\mathrm{NaCl}$ ) secara aseptik. Tingkat kekeruhan suspensi dibandingkan dengan standard 0,5 McFarland secara visual dan dilakukan pengukuran absorban dengan menggunakan spektrofotometer pada panjang gelombang $625 \mathrm{~nm}$, rentang absorbansi yang diperbolehkan adalah 0,08 - 0,13 yang setara dengan 1-2 x $10^{8} \mathrm{CFU} / \mathrm{mL}$ (Clinical and Laboratory Standards Institute, 2009) untuk uji dilusi. Kemudian dipipet sebanyak $100 \mu \mathrm{l}$ dan ditambahkan media dilusi (nutrient broth) hingga $10 \mathrm{ml}$ sehingga diperoleh suspensi mikroba dengan jumlah koloni 1-2 x $10^{6}$ CFU/ml (Wiegand dkk., 2008). Suspensi bakteri ini yang selanjutnya digunakan untuk uji aktivitas, dan harus digunakan tidak lebih dari 30 menit setelah pembuatan (Andrews, 2006). 


\section{Penyiapan sampel uji}

Larutan uji disiapkan dengan delapan macam konsentrasi larutan uji yaitu 2000, 1000, 500, 400, 300, 200, 100, dan $50 \mathrm{ppm}$. Konsentrasi sampel ini selanjutnya akan menjadi separuhnya di dalam microplate, yaitu menjadi 1000, 500, 400, 150, 100, 50 dan 25 ppm. Semua larutan uji dibuat dalam 5\% DMSO. Sebagai kontrol positif digunakan larutan siprofloksasin $50 \mathrm{ppm}$ dan kontrol negatif digunakan 5\% DMSO. Konsentrasi sampel uji, kontrol positif dan kontrol negatif akan menjadi separuhnya di dalam microplate karena dilakukan pengenceran 1:1.

\section{Penentuan konsentrasi hambat minimum (KHM)}

Konsentrasi hambat minimum merupakan konsentrasi terkecil dari sampel yang dapat menghambat pertumbuhan bakteri. Pada penelitian ini digunakan modifikasi metode mikrodilusi (Ellof, 1998). Sebanyak $50 \mu \mathrm{L}$ larutan uji dengan konsentrasi berurutan dari besar ke kecil dimasukkan ke dalam sumuran pertama hingga delapan. Pada sumuran sembilan ditambahkan $50 \mu \mathrm{L}$ larutan kontrol positif, sumuran berikutnya dimasukkan $50 \mu \mathrm{L}$ larutan kontrol negatif, dan sumuran sebelas dimasukkan $50 \mu \mathrm{L}$ media dan pada sumuran kedua belas dimasukkan $100 \mu \mathrm{L}$ media sebagai kontrol media (Gambar 1). Selanjutnya pada masing masing sumuran ditambahkan $50 \mu \mathrm{L}$ suspensi bakteri uji.

Microplate diinkubasi pada suhu $37^{\circ} \mathrm{C}$ selama sekitar 24 jam dan diamati terjadinya kekeruhan yang menandakan adanya pertumbuhan bakteri. Selanjutnya pada setiap lubang microplate ditambahkan $20 \mu \mathrm{INT}$ ( $p$ - iodonitrotetrazolium chloride) yang telah dilarutkan sebanyak $0,2 \mathrm{mg} / \mathrm{ml}$ aquades steril. 96-well microtiter plates diinkubasi kembali selama 10-60 menit pada suhu $37^{\circ} \mathrm{C}$ (Ellof, 1998). Apabila pada lubang plate terjadi kekeruhan dan disertai dengan perubahan warna menjadi merah setelah penambahan pereaksi warna INT maka menandakan adanya pertumbuhan bakteri.

\section{HASIL DAN PEMBAHASAN}

Uji aktivitas antibakteri ekstrak etanol $A$. cavernosa dilakukan terhadap bakteri Gram positif yaitu Staphylococcus aureus serta bakteri Gram negatif Pseudomonas aeruginosa dan Escherichia coli. Bakteri $P$. aeruginosa digunakan karena termasuk dalam bakteri patogen yang dapat menyebabkan penyakit pneumonia, infeksi saluran kemih, infeksi saluran pernafasan, sepsis, dan fibrosis kistik (Alhazmi,
2015), sedangkan bakteri yakni Escherichia coli dan Staphylococcus aureus bakteri ini ditemukan sebagai kontaminan makanan yang dijual secara tidak higienis sehingga sering menyebabkan penyakit saluran cerna dan diare (Tan dkk., 2014). Sebelum digunakan uji, semua bakteri uji diidentifikasi terlebih dahulu menggunakan pewarnaan Gram untuk memastikan bahwa bakteri telah sesuai. Koloni bakteri Gram positif akan berwarna ungu dan koloni bakteri Gram negatif akan berwarna merah. Perbedaan warna ini dikarenakan perbedaan struktur dinding sel bakteri dan perbedaan kandungan asam teiokat antara bakteri Gram positif dan bakteri Gram negatif. Bakteri Gram positif memiliki peptidoglikan yang mengandung asam teiokat sehingga dapat menghindari dekolorisasi warna kristal violet oleh alkohol. Sebaliknya untuk bakteri Gram negatif tidak memiliki asam teiokat sehingga mengalami dekolorisasi warna kristal violet oleh alkohol dan terbentuk warna merah pada pewarnaan dengan safranin (Forbes dkk., 2013). Hasil pengamatan menunjukkan bakteri S.aureus berwarna ungu dan berbentuk seperti bola yang tersusun berkelompok. Bakteri E.coli berwarna merah dan berbentuk batang pendek. Bakteri P.aeruginosa berwarna merah dan berbentuk basil-basil. Hasil ini menunjukkan bakteri yang digunakan sudah sesuai.

Pada penelitian ini uji aktivitas antibakteri dilakukan dengan metode mikrodilusi karena metode ini dapat memberikan hasil 30 kali lebih sensitif dibandingkan dengan metode difusi. Selain itu metode mikrodilusi dapat digunakan untuk analisis semikuantitatif hingga kuantitatif sehingga dapat menentukan KHM, tidak mahal, dan sampel yang digunakan relatif sedikit dibandingkan dengan metode makrodilusi (Ellof, 1998). Pada penelitian ini ditambahkan larutan pereaksi warna INT yang bertujuan untuk mengetahui adanya bakteri hidup secara visual pada setiap sumuran yang ditandai dengan adanya warna merah. Reaksi warna ini terjadi berdasarkan transfer elektron dari NAD+ menjadi NADH yang dikatalisa oleh TDH (Threonine dehydrogenase) yang berasal dari bakteri. Selama masa aktif pertumbuhan bakteri, elektron ditransfer dari NADH ke INT dan terjadi proses reduksi membentuk kristal formazan yang berwarna merah (Angeh, 2006). Sehingga bila terjadi pertumbuhan bakteri pada uji mikrodilusi ini akan timbul warna merah pada masingmasing lubang microplate yang masih ditumbuhi oleh bakteri. 


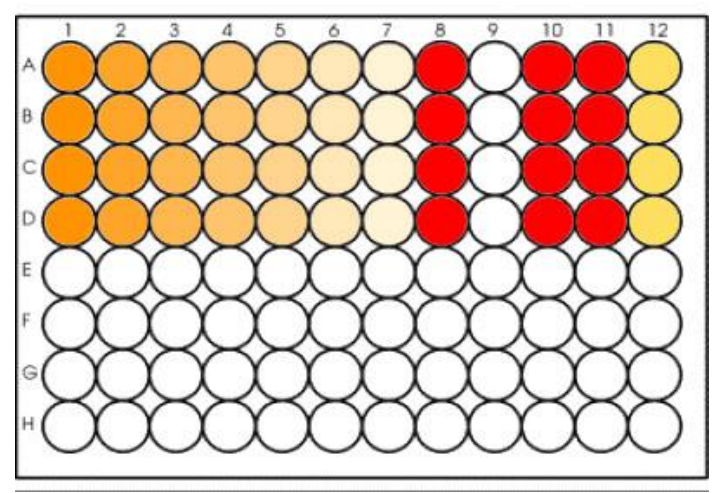

Gambar 1. Penempatan sampel uji dan kontrol pada microplate (Ilustrasi setelah penambahan INT).

Keterangan:

1: Sampel konsentrasi $1000 \mathrm{ppm}$

2: Sampel konsentrasi $750 \mathrm{ppm}$

3: Sampel konsentrasi $500 \mathrm{ppm}$

4: Sampel konsentrasi $200 \mathrm{ppm}$

5: Sampel konsentrasi $100 \mathrm{ppm}$

6: Sampel konsentrasi 75 ppm

7: Sampel konsentrasi 50 ppm (MIC)

8: Sampel konsentrasi 25 ppm

9: Kontrol + siprofloksasin

10: Kontrol -, 2,5\% DMSO

11: Kontrol pertumbuhan

12: Kontrol Media
Hasil yang diperoleh menunjukkan (Tabel 1) bahwa ekstrak etanol Agelas cavernosa dapat menghambat pertumbuhan Pseudomonas aeruginosa dengan KHM sebesar 150 ppm, Escherichia coli dengan KHM sebesar 200 ppm, Staphylococcus aureus dengan KHM sebesar 250 ppm. Berdasarkan pustaka, aktivitas antibakteri dapat dibagi menjadi 4 golongan berdasarkan harga KHM yakni KHM <100 ppm (tergolong kuat), KHM 100-500 ppm (tergolong sedang), KHM 500-1000 ppm (tergolong rendah), KHM >1000 ppm (tergolong tidak aktif) (Silva dkk., 2015). Berdasarkan hal tersebut dapat dinyatakan bahwa ekstrak spons $A$. cavernosa memiliki aktivitas antibakteri yang sedang terhadap ketiga bakteri tersebut. Beberapa faktor yang mempengaruhi proses uji aktivitas antibakteri antara lain konsentrasi bakteri yang ditambahkan pada agar (jumlah inokulum), adanya patogen kontaminasi), suhu pertumbuhan, waktu inkubasi dan kandungan nutrien (Bauer dkk., 1996). Selain itu faktor penting yang juga harus diperhatikan untuk mencapai hasil yang baik adalah galur mikroba uji yang digunakan karena pada galur yang berbeda terdapat perbedaan tingkat kepekaan.

Tabel 1. Hasil uji aktivitas antibakteri

\begin{tabular}{|c|c|c|c|}
\hline \multirow[t]{2}{*}{ Sampel } & \multicolumn{3}{|c|}{ Hasil Pewarnaan } \\
\hline & E. coli & S. aureus & P. aeruginosa \\
\hline \multicolumn{4}{|l|}{$1000 \mathrm{ppm}$} \\
\hline \multicolumn{4}{|l|}{$500 \mathrm{ppm}$} \\
\hline \multicolumn{4}{|l|}{$250 \mathrm{ppm}$} \\
\hline 200 ppm & & $\checkmark$ & \\
\hline $150 \mathrm{ppm}$ & $\checkmark$ & $\checkmark$ & \\
\hline $100 \mathrm{ppm}$ & $\checkmark$ & $\checkmark$ & $\checkmark$ \\
\hline $50 \mathrm{ppm}$ & $\checkmark$ & $\checkmark$ & $\checkmark$ \\
\hline 25 ppm & $\checkmark$ & $\checkmark$ & $\checkmark$ \\
\hline \multicolumn{4}{|l|}{ Kontrol + } \\
\hline Kontrol - & $\checkmark$ & $\checkmark$ & $\checkmark$ \\
\hline Kontrol tumbuh & $\checkmark$ & $\checkmark$ & $\checkmark$ \\
\hline MIC & $200 \mathrm{ppm}$ & $250 \mathrm{ppm}$ & $150 \mathrm{ppm}$ \\
\hline $\begin{array}{l}\text { Keterangan: } \\
\checkmark \text { menunjukkan a } \\
\text { Uji dilakukan de } \\
\text { quadruplo }\end{array}$ & $\begin{array}{l}\text { warna m } \\
\text { tiga kali }\end{array}$ & $\begin{array}{l}\text { sumuran } \\
\text { masing } n\end{array}$ & lilakukan secar \\
\hline
\end{tabular}

\section{KESIMPULAN}

Ekstrak etanol $96 \%$ spons Agelas cavernosa yang diambil dari utara pulau Barrang Lompo, Makassar memiliki aktivitas antibakteri terhadap E. coli, S.aureus dan $P$. aeruginosa dengan aktivitas tertinggi terhadap bakteri $P$. aeruginosa dengan KHM sebesar 150 ppm.

\section{DAFTAR PUSTAKA}

Abubakar, H., Wahyudi A. T. \& Yuhana, M. (2011). Skrining Bakteri yang Berasosiasi dengan Spons Jaspis sp. Sebagai Penghasil Senyawa Antimikroba. Ilmu Kelautan; 16; 35-40.

Alhazmi, A. (2015). Pseudomonas aeruginosaPathogenesis and Pathogenic Mechanisms. International Journal of Biology; 7; $44-67$. 
Andrews, J. M. (2006). Determination of Minimum Inhibitory Concentration. Journal of Antimicrobial Chemotherapy; 48; 5-16.

Angeh, J. E. (2006). Isolation and Characterization of Antibacterial Compounds. Thesis; University of Pretoria, South Africa.

Bauer, A. W., Kirby, W. M., Sherris, J. C. \& Turek, M. (1996). Antibiotic Susceptibility Testing by a Standardized Single Diskmethod. American Journal of Clinical Pathology; 45; 493-498.

Clinical and Laboratory Standards Institute. (2009). Performance Standard for Antimicrobial Disk Susceptibility Test; Approved Standard.10 ${ }^{\text {th }}$ ed. Pennsylvania.

Eloff, J. N. (1998). A Sensitive and Quick Microplate Method to Determine the Minimal Inhibitory Concentration of Plant Extracts for Bacteria. Planta Medica; 64; 711-713.

Forbes, B. A., Sahm, D. F. \& Weissfeld, A. S. (2007). Bailey and Scott's: Diagnostic Microbiology. Virginia: Mosby Inc.

Haris, A., Arniati \& Werorilangi, S. (2013). Uji Antibakteri Patogen Ekstrak Sponge Menggunakan Metode High Troughput Screening (HTS) dengan Indikator MTT (3-[4,5dimethylthiazol-2-yl]-2,5diphenyltetrazolium bromide). Laporan penelitian; Universitas Hasanudin, Makassar.

Kementerian Kesehatan Republik Indonesia. (2011). Peraturan Menteri Kesehatan Republik Indonesia Nomor 2406/MENKES/PER/XII/2011 Tentang Pedoman Umum Penggunaan Antibiotik. Jakarta: Kemenkes RI.

Kim, S. K. (2012). Marine Pharmacognosy: Trends and Applications. New York: CRC Press.

Medeiros, A. M., Lourenco, A., Tavares, M. R., Joao, M., Curto, M., Savluchinske, F. \& Roseiro, C. (2006). Agelasidine A from Agelas clathrodes. Journal of Biosciences; 61; 472-476.
Mokodompit, A., Boekoesoe, L. \& Mustapa, M. A. (2015). Uji Aktivitas Antibakteri Ekstrak Etanol Spons Laut (Porifera:Demospongiae) terhadap Bakteri Staphylococcusaureus dan Escherichia coli. Laporan penelitian; Universitas Negeri Gorontalo, Gorontalo.

National Institutes of Health, United States Department of Health and Human Services. (2014). Stop the Spread of Superbugs: Help Fight Drug-Resistant Bacteria.

https://newsinhealth.nih.gov/2014/02/stop-spreadsuperbugs. Accessed: 21 Juni 2018.

Silva, N. M. M., Silva, I. S. M., Pires, R. F. S., Vasconcelos, T. L. C., Viana, M. D. M., Campessato, E. A., Conserva, L. M., Rocha., E. M. M., Araujo, E.C., Araujo, Jr.J.X. \& Bastos, M.L.A. (2015). In Vitro Evaluation of Antimicrobial, Antioxidant, dan Larvicidal Activities from Extract of Zeyheria tuberlusa (Vell) Bur. (Biognoniace). Journal of Chemical and Pharmaceutical Research; 7; 319-328.

Tan, S. L., Lee, H. Y., Mahyudin, N. A. (2014). Antimicrobial Resistance of Escherichia coli and Staphylococcus aureus Isolated from Food Handler's Hands. Food Control; 44; 203-207.

Wiegend, I., Hilpert, K. \& Hancock, R. E. W. (2008). Agar and Broth Dilution Method to Determine the Minimal Inhibitory Concentration (MIC) of Antimicrobial Substances. Nature Protocols; 3; 163-175.

World Health Organization. (2018). Antimicrobial Resistance.

http://www.who.int/mediacentre/factsheets/fs194/ en/. Accessed: 28 Maret 2018.

Yamazaki, H., Abdjul, D. B., Kanno, S. I., Takahashi, O., Kirikosho, R., Ukai, K. \& Namikoshi, M. (2015). Structures and Biological Evaluations of Agelasines Isolated from the Okinawan Marine Sponge Agelas nakamurai. Journal of Natural Products; 79; 1149-1154. 